\title{
Does Green Banking Performance Pay Off? Evidence from a Unique Regulatory Setting in Bangladesh
}

Running Title: Green Banking Performance

\author{
Sudipta Bose* \\ Discipline of Accounting and Finance \\ Newcastle Business School \\ University of Newcastle \\ Sydney, NSW 2000, Australia \\ Tel: +61282626406 \\ Email: sudipta.bose@newcastle.edu.au
}

\section{Habib Zaman Khan}

School of Accounting and Finance

University of Canberra

Bruce, ACT 2617, Australia

Tel: +61262015839

Email: habib.khan@canberra.edu.au

\author{
Reza M. Monem \\ Department of Accounting, Finance and Economics \\ Griffith University \\ 170 Kessels Road, Qld 4111, Australia \\ Tel: +61 737353598 \\ Email: r.monem@griffith.edu.au
}

Acknowledgement: We would like to thank the two anonymous reviewers for their constructive comments and suggestions. We are also grateful to Associate Professor Bo Qin (Assigned Editor) and Professor Konstantinos Stathopoulos (Editor-in-Chief) for their helpful guidance throughout the review process.

Author names appear in alphabetical order.

*Corresponding author: Sudipta Bose, Discipline of Accounting and Finance, University of Newcastle, Sydney, NSW2000, Australia. Tel: +61 28262 6406;

Email: sudipta.bose@newcastle.edu.au 


\title{
Does Green Banking Performance Pay Off? Evidence from a Unique Regulatory Setting in Bangladesh
}

\begin{abstract}
Manuscript Type: Empirical

Research Question/Issue: A firm's choice to 'go green' largely remains unregulated worldwide. This study uses an institutional setting in Bangladesh experiencing a green banking regulatory reform to examine whether banks' green performance translates into improved financial performance and whether this is moderated by banks' political connections.

Research Findings/Insights: Results based on a sample of 172 firm-year observations from 2008-2014 suggest that green banking performance is positively associated with a bank's financial performance. Further analysis suggests that cost efficiency mainly drives this relationship. However, banks' political connections negatively affect this relationship by counterbalancing green banking's non-financial benefits. Our findings are robust to sensitivity tests which examine endogeneity concerns using difference-in-differences (DiD) and propensity score matching (PSM) analyses and Heckman's (1979) two-stage analysis.
\end{abstract}

Theoretical/Academic Implications: Most prior studies on corporate social responsibility (CSR) were conducted in voluntary settings: however, our study utilises a unique regulatory setting in Bangladesh. With this exogenous shock to the banking industry, the regulatory setting helped to alleviate endogeneity concerns arising from voluntary motives behind CSR performance. To the best of our knowledge, this is the first study to examine any link between green banking performance in a regulatory setting and banks' financial performance.

Practitioner/Policy Implications: This study's findings suggest that sustainable business practices promoted through regulatory intervention can improve financial performance. A regulatory green banking initiative can be a win-win for all competing stakeholders. Our findings have significant policy implications for governments and regulatory agencies worldwide in the fight against global warming and climate change.

Keywords: Green banking performance, Regulatory setting, Banking industry, Financial performance, Political connections, Emerging economy.

JEL Classifications: G21; G34; M14; M41 


\section{INTRODUCTION}

Sustainable business (SB) practices through green and corporate social responsibility (CSR) practices are promoted today as key strategies in the fight against global warming and climate change (e.g., Porter \& Reinhardt, 2007; KPMG, Global Reporting Initiative [GRI], United Nations Environment Programme [UNEP] \& Centre for Corporate Governance in Africa, 2016; International Finance Corporation [IFC], 2017). To date, SB practices (including green and CSR practices) have largely remained unregulated worldwide. As they are voluntary in nature, disclosures of these practices are largely self-laudatory (e.g., Deegan \& Rankin, 1996). Moreover, the motivations for these practices can vary substantially across firms, as well as having a confounding effect through their relationship with a firm's financial performance (FP). For example, Wu and Shen (2013; hereafter, WS) argue that, in a voluntary setting, the relationship between CSR and FP can be positive, non-negative and non-existent depending on the CSR motives.

In this study, we examine whether green banking (GB) performance ${ }^{1}$ is associated with improved FP in banks within a unique regulatory setting in Bangladesh. The essence of GB lies in a bank's focus on sustainability, resource efficiency and environmental friendliness both in its internal operations and external engagement. Specifically, while CSR refers to a bank's behaviour emanating from a sense of accountability towards external stakeholders, GB requires a primary focus on environmental sustainability both in internal operations as well as in its role of influencing clients towards sustainability.

The innovation of this study stems from its focus on a regulatory setting which is not the case in most prior SB studies. Unlike the voluntary settings of most CSR studies, our study is premised on the GB regulatory setting in Bangladesh. Moreover, focusing on a single industry potentially controls for drivers that are correlated with industry characteristics and hence offers a better setting in which to tease out any GB-FP relationship. 
A related study is the work of WS; however, our study differs in several dimensions. Firstly, unlike the voluntary setting used by these authors, a regulatory setting is used in our study to investigate the GB performance-FP link. Thus, unlike WS's study, our study's findings are unlikely to suffer from self-selection bias due to the voluntary nature of CSR motives. Secondly, unlike WS, our study focuses on a single country. Thus, our results are immune to institutional differences across sample countries in cross-country settings. Thirdly, WS focus on CSR activities, while our study focuses on GB activities that go beyond CSR engagement and are more proximal to banks' business models and operations. In the next section, the differences between GB and CSR are discussed in detail. Fourthly, WS focus on FP measured in accounting-based terms (i.e., return on assets [ROA] and return on equity $[\mathrm{ROE}]$ ) whereas we focus on a market-based measure (Tobin's Q). ${ }^{2}$

The banking industry is our study's focus due to its growing significance in the global economy over time. For example, domestic credit to the private sector as a percentage of the world's gross domestic product (GDP) grew from 52.03\% in 1960 to $129.73 \%$ in 2018 (World Bank, 2020). Moreover, banks are coming under heightened scrutiny from social and environmental activists for their role in financing large projects that often potentially contradict efforts towards a sustainable, low-emission economy. For example, environmental activists warned Australia's four largest banks against funding the controversial Carmichael coal mine (Sky News, 2017). Similarly, in 2012, the ANZ Bank in Australia was forced to abandon financing a controversial Tasmanian pulp mill project after intense lobbying from environmental groups (ABC News, 2012). Examples of similar activism against banks are available from Europe. ${ }^{3}$

Green and environmental regulation is particularly important for emerging economies as these economies are vulnerable to global warming and climate change. Initiatives like green and environmental policies and climate change policies undertaken by different policy makers 
in emerging economies are very relevant and timely in decarbonising economies and limiting climate warming to below $2^{\circ}$ Celsius (United Nations Framework Convention on Climate Change [UNFCCC], 2016). Bangladesh, an emerging economy, was chosen as our research setting for three reasons. Firstly, Bangladesh is one of the early GB adopters, with GB-related regulation introduced in the country in 2011 (for a detailed discussion, see the next section). ${ }^{4}$ Most countries adopting GB initiatives are emerging economies, with the Bangladeshi experience likely to be informative for them. Secondly, banks in Bangladesh have strong incentives to comply with GB regulation as significant economic benefits are associated with compliance (see next section). Thirdly, as Bangladesh is potentially one of the worst victims of global warming (World Bank, 2013; Verisk Maplecroft, 2015; World Bank, 2016), the people and corporations of Bangladesh are likely to have a strong interest in policies and practices aimed at mitigating the effects of both global warming and climate change. Moreover, like other emerging economies/developing countries affected by global warming, Bangladesh's access to the United Nations (UN) Climate Fund will partly depend on its own initiatives in climate mitigation and adaptation.

Implicitly, the central research question addressed in our study is why banks that 'do good' can also do well financially. ${ }^{5}$ In the regulatory setting such as green regulation in Bangladesh, when banks modify internal operations and business models that 'do good' either to the planet or, at least, minimise environmental harm. Banks in this regard do not necessarily have to incur sunk costs. Alterations in business operations and the adoption of models can achieve cost savings, revenue growth (through product innovations) and improvements in efficiency and expediency at the firm level. These efforts by banks can also be appealing to customers, stockholders, and other stakeholders. For example, while online banking services require significant bank investment in technology and personnel, their net effect can be cost savings and improved banking services. In turn, this may lead to cost savings as the expansion 
of online banking services is likely to reduce the need for large on-site operations and staff presence for face-to-face customer interactions, while also reducing branch operating costs including rent, electricity, furniture, and stationery. On the other hand, online banking services may lead to non-financial benefits for banks. For example, they may significantly improve customer satisfaction through quick service delivery without the customer needing to travel, as well as minimising errors and omissions because of electronic records and increasing the expediency of access to banking services at any time and from anywhere. Minimising the travel of bank customers and, potentially, of bank employees is good for the planet in terms of the reduction of carbon emissions, traffic congestion, and wastes. At the same time, environmentally friendly bank operations are likely to attract clients, broader stakeholders and potential large-scale investors who place importance on fighting global warming in their daily life. Finally, with GB's emergence and the focus of bank decision makers on making business decisions not from purely economic perspectives, but also from environmental perspectives, current and potential investors will be likely to appreciate banks' efforts towards improving their market reputation which, in turn, will improve banks' financial performance (FP).

However, all green initiatives are not purely driven by the motive to fight global warming and climate change at all time. Banks, like any other firms in the economy, are living organisms within the larger system of society. Institutional, contextual, and socio-economic environments shape and re-shape the conduct, norms and management practices of firms (Bansal \& Roth, 2000; Brooks \& Oikonomou, 2018). As such, bank behaviour is also likely to be influenced by the dynamics of society. Given the political environment in Bangladesh, political connections of business corporations are highly prevalent (Muttakin, Monem, Khan, \& Subramaniam, 2015) and, in some cases, they are quite extreme. ${ }^{6}$ Thus, banks' propensity to comply with green regulations could be politically motivated as well. Stakeholders in this regard are likely to react negatively to these politically motivated green activities of banks. The 
underlying mechanism through which political connection might have an adverse effect in the GB-FP relationship is through causing reputational damages of banks and wastage of green funds. Specifically, since the political connection of banks indicates poor corporate governance, banks with highly politically connected will likely impair market reputation in the long run, leading to increased customer and stakeholders' dissatisfactions. Moreover, politically connected banks' may not achieve an efficient way of managing green funds as politically powerful leaders misuse funds for their personal interest than promoting banks' green performance (Khan, Bose \& Johns, 2020). Consequently, we also investigate whether the relationship between GB and a bank's FP is moderated by the bank's political connections.

In our study, we measure bank-level GB performance using an index comprising 21 items which can be categorised into three components: cost efficiency, revenue growth and non-financial benefits. A positive association between GB performance and a bank's FP is expected. While the roles of cost efficiency and revenue growth in FP are obvious, activities and commitments (e.g., tree planting, green marketing, receiving environmental awards) listed under GB's non-financial benefits can enhance a bank's GB credibility and make it more appealing to green activists and other stakeholders who care about the environment (Ambec \& Lanoie, 2008; Porter, 1991). Thus, banks' FP is likely to be improved by GB activities classified under non-financial benefits.

The current study's results, based on a sample of 172 banking firm-year observations from 2008-2014, suggest that higher FP is more likely to be exhibited by banking firms with greater GB performance. For example, a one standard deviation increase in the GB performance index is associated with a 9.43\% increase in the standard deviation of Tobin's Q. In further analysis, our study identifies that FP improves mostly through GB's cost efficiency. However, the potential for reputational damage caused by a bank's political connections nullifies the effect of GB's non-financial benefits in FP improvement. The reason is that 
corporate political connections in Bangladesh often encourage firm owners/managers to engage in politically motivated green activities that please political leaders at the expense of benefits for all stakeholders.

Our study's results are robust to several sensitivity tests. For example, we apply out-ofsample difference-in-differences (DiD) and propensity score matching (PSM) analyses to address any endogeneity concerns in our results. To address simultaneity bias arising from potential reverse causality, the study employs dynamic panel data models using the system known as the generalised method of moments (GMM), as developed by Blundell and Bond (1998). Furthermore, we employ Heckman's (1979) two-stage regression technique to address sample selection bias.

Our study's contribution to the literature is fourth fold. Firstly, we study the GB-FP relationship using a regulatory setting which helps to alleviate the endogeneity concerns of voluntary settings. This is important given that most CSR and FP studies, including that of WS, are premised on voluntary settings. Secondly, to the best of our knowledge, our study is one of the first to address the impact of GB performance on the FP of banks. The study focuses on a bank's commitment to the sustainability agenda (green banking agenda in particular) that goes beyond CSR and directly shapes the bank's business model, whereas prior studies investigate CSR activities that are less proximal to a bank's business operation (e.g., Clarkson, Li, Richardson, \& Vasvari, 2011; Wu \& Shen, 2013; Cahan, de Villiers, Jeter, Naiker, \& van Staden, 2016). Thirdly, we extend the non-financial performance accounting literature by documenting evidence of non-financial activities that have indirect benefits on the FP of banks. Lastly, we contribute to the literature by providing key insights into the role of contextual factor (e.g., the adverse impact of political connections of banks) in the relationship between GB performance and FP; this type of research endeavour is barely available in the green banking/sustainability literature. Overall, our findings suggest that sustained economic 
development can be achieved through good environmental behaviour, thus offering hope for environmental activists and for those who advocate economic growth at the expense of the environment. At the same time, our findings have major policy implications for governments, bank regulators and policy makers interested in sustainable economic development while addressing global warming.

The remainder of the paper is structured as follows. A discussion on GB and the research context is given in the next section. The literature review, theoretical framework and hypotheses development are discussed in the third section, while the fourth section presents the study's methodology, and the fifth section discusses its empirical findings. The sixth and seventh sections, respectively, explain the endogeneity and robustness analyses. The final section concludes the paper and addresses the study's implications and limitations.

\section{CONCEPTS OF GREEN BANKING AND GREEN BANKING REGULATION IN BANGLADESH}

\subsection{Concept of Green Banking (GB)}

In broad terms, green banking (GB) refers to banks carrying out and assisting in environmentfriendly practices in their internal and external operations. The objective is to reduce banks' carbon footprints, work better with clients on green activities and monitor green initiatives across the value chain partners of banks' business operations (Fenn, 2012). A United Nations

Development Programme (UNDP) (2014) report defined green banking as:

a method of finance that encourages environmentally responsible investment, extending priority to enterprises and industries that attempt to 'grow' green. One way the banking system can go green is by going online. Online bill payment, remote deposits, fund transfers, and statements are other ways in which online banking can help preserve the environment, reducing the use of paper, energy, and natural resources in banking activities. Similarly, by supporting clients' projects that use energy-saving devices, green loans can promote eco-friendly house building (p. 44).

On at least three dimensions, GB is distinct and different from the traditional CSR concept. Firstly, CSR mainly focuses on how a firm addresses its social agenda (e.g., equal 
employment opportunities, non-discrimination, empowering women) and negative externalities, such as air, water and land pollution. To counter their negative image, firms publicise their involvement in positive social activities, such as philanthropy and initiatives that promote the social good. In contrast, GB is a business model through which banks directly contribute to sustainable economic development by, on the one hand, prioritising the financing of 'green' projects while, on the other hand, making their own internal operations more 'greenfriendly'. Secondly, the CSR focus is to appeal to secondary stakeholders such as society at large or environmental activists. Conversely, the GB focus is to make changes within banks, influencing banks clients', borrowers, and their value chain partners towards sustainable economic development via green-friendly projects. Thirdly, GB regulation uses a holistic approach to change the way that traditional banks 'think', whereas legislation relating to CSR covers only certain aspects of the operation of a firm or industry (e.g., air and water pollution, employee safety standards).

\subsection{Green banking (GB) regulation in Bangladesh}

Bangladesh is one of the first countries to have moved toward GB regulation (The Guardian, 2014). Bangladesh Bank (BB), the country's central bank and the banking sector regulator, has been at the forefront of introducing green finance. Several measures that have accelerated GB in Bangladesh's banking sector include policy guidelines, concessional refinancing schemes, donor-supported sector-specific transformational projects and credit quotas for financial institutions (United Nations Environment Programme (UNEP), 2015).

In 2011, Bangladesh Bank issued GB Policy Guidelines instructing commercial banks to adopt and implement an inclusive policy for GB activities in three phases. In phase 1, banks needed to develop an environmental policy, integrated with internal operations and lending strategies, and to form a separate GB unit. In phase 1, banks also needed to create high-level supervisory committees to review and monitor their designated policies and strategic 
interventions and to allocate budgets for green finance, climate risk funds and internal capacity development (Bose, Khan, Rashid, \& Islam, 2018). In phase 2, banks were directed to formulate sector-specific financing policies for bank clients while being mindful of the environmental sensitivity of clients' businesses, to establish green branches, to incorporate environmental issues into formal credit risk criteria, to develop an environmental risk management manual for assessing and monitoring projects, and to undertake external disclosure of GB activities (Bose et al., 2018; Khan, Ali, \& Fatima, 2014). In phase 3, banks were required to design new innovative products and to publish verifiable reports on GB activities in a standardised format (Bangladesh Bank [BB], 2014).

In recent years, two new policy guidelines were introduced by the Bangladesh Bank. The first guideline set a minimum direct green finance target of 5\% for total loan disbursements from January 2016 onwards for all scheduled banks. Banks and financial institutions were also directed to form a 'climate risk fund', allocating at least $10 \%$ of their CSR budget to this fund. The second guideline issued in May 2016 instructed banks and financial institutions to set up solid waste management systems, rainwater harvesting and solar power panels for their office buildings by the end of 2018, and to encourage clients to install environmentally-friendly facilities in new infrastructure built through bank finance.

Bangladesh Bank has introduced incentives for banks to adopt green initiatives. These incentives, serving as a 'stimulus package', have created exciting opportunities for Bangladesh banks to 'go green' and comprise: (i) access to a refinancing scheme (commercial banks obtain subsidised-rated loans for different green products from Bangladesh Bank, lending to clients at the market rate, thus increasing their interest margin); (ii) access to climate risk funds established by Bangladesh Bank; (iii) allocating additional points for banks' initiatives for green and sustainability practices in regulatory assessment (the CAMELS rating) ${ }^{7}$; (iv) provision of preferential permission to open new branches; and (v) concessions on tax liabilities 
in agreement with the National Board of Revenue $(\mathrm{NBR})^{8}$ (Asian Development Bank [ADB], 2018; BB, 2012; Khan et al., 2020). Even though no financial penalty is imposed in the GB guidelines for non-compliance, commercial banks must explain their reasons for noncompliance to the central bank (Khan et al., 2020). In the event of non-compliance, banks cannot access the benefits listed earlier and fail to be on good terms with the central bank. As a result, unlike other settings both in developed and emerging economies where 'hard' regulation on sustainability is evidenced (e.g., United Kingdom, other European countries, and India) (CSR Europe and GRI, 2017; Manchiraju and Rajgopal, 2017), the regulatory feature in Bangladesh is considered as 'soft' regulation, which makes the settings unique, distinctive and interesting to explore.

Recent empirical evidence suggests that, although the substantial variation is apparent across banks, the overall level of compliance with the regulatory guidelines has significantly improved since their 2011 introduction (Bose et al., 2018). For example, the total value of green finance increased from Bangladesh taka (BDT) 270.92 billion in 2012 to BDT 548.62 billion in 2016 (BB Annual Reports, 2012-2016).

\section{LITERATURE REVIEW, THEORETICAL FRAMEWORK AND HYPOTHESES DEVELOPMENT}

\subsection{Green banking (GB) and financial performance (FP)}

Green and environmental regulations can produce win-win situations for firms and the community (Porter, 1991). Properly designed environmental regulations enable firms to embrace innovations in products, processes and services (Porter \& van der Linde, 1995a, 1995b). Improved green performance tends to increase revenue growth as firms attempt to differentiate with green products or facilitate greater access to new markets (Ambec \& Lanoie, 2008; Porter \& van der Linde, 1995a). Similarly, firms' stronger green performance can reduce 
operating costs and the risks of breaching green regulations (Ambec \& Lanoie, 2008; Orsato, 2006; Porter \& van der Linde, 1995a, 1995b).

Capital markets welcome information on firms' green performance. Prior studies provide evidence that firms create a positive impression in the eyes of different stakeholders when they improve their green and environmental performance (Prior, Surroca, \& Tribó, 2008; Diouf \& Boiral, 2017). Disclosure of GB performance information potentially reduces information asymmetry between firms and market participants. Specifically, high-quality green performance information attracts ordinary uninformed investors to the capital market (Brown \& Hillegeist, 2007). Our study argues that reduced information asymmetry (via GB disclosures) is likely to lead to higher firm value through two channels. On the one hand, increased disclosure of GB performance is likely to facilitate more precise estimation of bank earnings by analysts and investors. On the other hand, reduced information asymmetry is likely to lower the ex-ante cost of equity capital (Hughes, Liu, \& Liu, 2007). Taken together, increased GB performance is likely to lead to higher bank valuation.

Within the accounting literature, Clarkson, Li and Richardson (2004) document that good green performance brings diverse benefits for firms over and above compliance (e.g., building "green goodwill", process innovations and raising rivals' costs), while poor green performance is associated with negative investor reaction emanating from environmental liabilities and other damages faced by firms. Similarly, Al-Tuwaijri, Christensen and Hughes (2004) find good environmental performance to be positively associated with good economic performance. Using data from the four most-polluting industries ${ }^{9}$, Clarkson et al. (2011) show that firms that improve their environmental performance experience much better FP in the future. The underlying logic is that enhanced green performance leads to revenue growth, improved reputation and higher market value (Clarkson et al., 2004; Griffin \& Sun, 2013). ${ }^{10}$ 
In the banking industry context, Scholtens and Dam (2007) provide useful insights on the differences in CSR engagement between banks that adopted the Equator Principles and those that did not (see also Scholtens, 2009). Other studies document the link between banks' CSR disclosures and stakeholders' perceptions of these disclosures (Khan, Halabi, \& Samy, 2009), the determinants of banks' CSR disclosure (Bose, Bhattacharyya, \& Islam, 2016; Khan, 2010) and the evidence of banks sustainability disclosure using GRI framework (Khan et al., 2011). However, to date, no empirical evidence is available on banks' GB performance-FP link.

In 2010, the Bangladesh government created green funds from its own budget, initially around US\$100 million, which significantly increased on a year-on-year basis to approximately US\$400 million in 2017 (ADB, 2018). As discussed earlier, Bangladesh Bank promulgated green performance guidelines and directives making banks not only engage in GB activities and reporting but also creating economic incentives for banks' good behaviour. More importantly, commercial banks in Bangladesh are now required to provide verifiable GB reports to the regulator (Bangladesh Bank) on an annual basis.

From the above discussion, in our study, we expect that banks with stronger GB performance will also exhibit FP that is stronger. We argue that GB performance will improve FP through three channels. Firstly, modifying traditional banking services to increasingly online services will engender costs savings through reduced demands for bank personnel, office space and banking stationery. Secondly, online banking will improve service efficiency, reduce customer service errors and improve customer satisfaction through convenience and speed. Thirdly, GB performance will not only directly affect revenue growth (through innovative banking products and potential access to new markets) but will also complement other appreciation through stakeholder recognition of activities (e.g., tree planting, green marketing, 
environmental awards) as well as customer and community satisfactions. Thus, we hypothesise the following:

H1: Green banking performance in Bangladesh is positively associated with banks' financial performance.

\subsection{Green banking (GB) and financial performance: The role of political connections}

Brooks and Oikonomou (2018) argue that it is essential to consider other contingencies and contextual factors that may affect the environmental performance-FP relationship. They suggest examining the role of moderating factors to better understand this relationship. Arguably, we recognise that the GB-FP link is conditional on key factors associated with the context in which bank operations are embedded. Given the prevalence of corporate political connections in Bangladesh (Muttakin et al., 2015), we explore whether the political connections of banks in Bangladesh have any moderating effect on the GB-FP relationship.

Members of Bangladesh's corporate sector regularly participate in the political process and maintain strong relationships with political leaders and their families through financial contributions to the major political parties (Chowdhury, 2009). In return, corporate sector members wield different levels of power. For example, political connections assist firms to exploit any weaknesses in the institutional environment (Ahmed \& Uddin, 2018). These connections also ensure economic benefits limited to powerful and dominant shareholders such as favourable regulations, government protection, deliberate avoidance of loan repayments and by-passing of regulatory guidelines on green initiatives (Ahmed \& Uddin, 2018; Khan et al., 2020; Muttakin et al., 2015). Political connection of banks impairs green performance. Specifically, corporate political connections often encourage firm owners/managers to engage in politically motivated green activities that please political leaders at the expense of benefits for all stakeholders (Uddin, Siddiqui, \& Islam, 2016). Overall, the political connection of banks 
tends to decrease banks' market reputation and increase both depositors' and other stakeholders' dissatisfactions.

Similarly, owing to the connection of banks with politically powerful people, it is evidenced that banks are unable to use green loans/green funding economically and efficiently. Recent evidence, both anecdotal and empirical, suggests that, within the culture of high loan defaults in Bangladesh (The Independent, 2017), loans for green and environmental projects are, at times, misused and, when granted for political reasons, become uncollectable (Khan et al., 2020). For example, political leaders use green funds to promote their personal agendas by deliberately exploiting and abusing funding, distributing loans to people within their political networks rather than to the most disadvantaged, such as widows running small businesses (Uddin et al., 2016). With the blessing of chairmen and directors of banks, political affiliates and political leaders become unaccountable for the disbursement of funds (Khan et al., 2020; The Independent, 2017). These practices exert great pressure on regulatory initiatives for green programs. $^{11}$ Essentially, the connection of banks with politically powerful actors and interference of political leaders display poor governance for the banking industry. Indeed, political leaders cause damage to banks market reputations, attract media criticism, customers and general shareholders dissatisfaction, including banks initiatives for green performance. Thus, we argue that commercial banks' political connections in Bangladesh and the close interactions of bank executives with political leaders seriously discount the intent of GB performance. Politically motivated GB activities do misguide and waste green resources, serving only to feed the political ambitions of bank executives. This, in turn, it raises doubts about the credibility of GB performance of politically connected banks. In summary, we argue that politically connected banks will not fully benefit from their GB performance and that banks' political connections will have a negative moderating role on the GB-FP link. Formally, we propose the following: 
H2: Political connections of banks in Bangladesh negatively affect the positive association between green banking performance and financial performance.

\section{RESEARCH DESIGN}

\subsection{Sample and data}

The sample for this study comes from the banking sector in Bangladesh from 2007-2014. The sample begins in 2007, owing to inadequate disclosure of banks' GB performance prior to 2007, and ends in 2014, the final year of data collection. Thus, our initial sample comprised 397 banking firm-year observations. However, we excluded 158 observations as these observations were related to banks not listed on either of the two stock exchanges. ${ }^{12}$ Next, we dropped 37 observations due to missing financial data and excluded 30 observations due to our lead-lag analysis approach. The final sample comprised 30 banking firms with 172 banking firm-year observations. Although our sample size is small, it is comparable to prior studies. For example, Bose, Podder, and Biswas (2017a) used 137 banking firm-year observations, and Sobhan (2016) employed 91 observations when taking into consideration the uniqueness of GB data. We collected financial and stock market data from the Compustat Global database and hand-collected corporate governance, ownership and directors' data from annual reports. We also hand collected GB performance data from banks' annual reports.

\subsection{Measures of green banking (GB) performance}

Our study developed an index consisting of 21 items that relate to GB performance. These items were obtained from the directive issued by Bangladesh Bank, the bank regulator. To develop the index, the GB performance items were categorised into three key groups: cost efficiency, revenue growth and non-financial benefits. Cost efficiency consisted of performance relating to a banking firm's cost savings due to undertaking GB activities. Revenue growth comprised performance items that help banks to generate more revenue, and 
non-financial benefits consisted of performance items from which banking firms derive indirect benefits other than cost savings and revenue growth. Appendix A, Panels A, B and C present the list of 21 items.

A performance index is considered less reliable if it is constructed based on firms' voluntary disclosures. However, it is argued that a performance index is more reliable if it is developed based on regulatory direction (Tauringana \& Chithambo, 2015) as this type of index reflects the firm's accountability specific to the context in which it operates. To measure GB performance, we relied on Bangladesh Bank's directive as a government-developed performance checklist on GB instead of using established indices (e.g., the Global Reporting Initiative [GRI]). As our GB performance index (GBPI) reflects the directions of Bangladesh Bank (the bank regulator), we argue that our study's GB performance index is less subject to the self-selection bias.

We employed content analysis to quantify GB performance information disclosed in banking firms' annual reports. ${ }^{13}$ This analysis technique has been extensively used in the literature (e.g., Khan, Bose, Mollik \& Harun, 2020; Tauringana \& Chithambo, 2015). Performance can be quantified by using either a weighted or an unweighted approach (Cooke, 1989; Khan et al., 2020; Tauringana \& Chithambo, 2015). In this study, we utilised an unweighted approach in which every item of performance in the index is deemed to be equally important (Cooke, 1989). We assigned a score of 1 if a bank reported a specific GB activity that matched our list and a score of 0 if it did not. Based on this scoring technique, we first developed the overall GB performance index (GBPI). We then decomposed the overall index into three components: cost efficiency, revenue growth and non-financial benefits.

The overall GBPI captured the ratio of aggregate performance score to the maximum possible performance score (i.e., 21) for each firm year. A higher GBPI score indicated a higher level of GB performance. We used a similar process to develop the indices for cost efficiency, 
revenue growth and non-financial benefits. Also, to assess our GBPI's internal consistency, we employed Cronbach's alpha coefficient, following Bose, Saha, Khan, and Islam (2017b). ${ }^{14}$ The alpha coefficient for the GBPI is 0.776 , suggesting that the items in the performance index capture the same underlying constructs. ${ }^{15}$

\subsection{Measures of political connections}

The political connections data were identified from various sources. Following Muttakin et al. (2015), we used the Bangladesh Election Commission (BEC) website to identify the list of candidates who participated in the Bangladesh national parliamentary election held on 29 December 2008. We then matched candidates' names with the board of directors' data from banks in our sample. The names of political party committee members and advisory council members were sourced from parties' websites. Finally, directors' affiliations with political parties through standing as party candidates at the national election and/or serving as party officials were validated by conducting internet searches, and by accessing online versions of major daily newspapers in Bangladesh during our sample period. Interestingly, the political connections of banks in Bangladesh are quite visible. If a bank's director is a member of parliament, this information is usually disclosed in the bank's annual report. In our sample, if a bank director was a member of parliament, a minister or had a close relationship with a politician, the banking firm was defined as politically connected (PCON). Our definition of political connections is consistent with that used in prior research (e.g., Faccio, 2006).

\subsection{Measures of financial performance (FP)}

Following prior studies (Kale, Reis, \& Venkateswaran, 2009; Bebchuk, Cremers, \& Peyer, 2011; Li, Minnis, Nagar, \& Rajan, 2014; Cahan et al., 2016), we use TOBINQ (Tobin's Q) as a measure of a bank's FP. TOBINQ is measured as the ratio of book value of total assets plus market value of equity minus book value of equity to total assets. We use Tobin's Q instead of accounting-based measures of performance as it signals a firm's future growth prospects and 
the sustainability of profits or expected performance (Luo \& Bhattacharya, 2006; Bose et al., 2017a). This measure is risk-adjusted and less susceptible to changes in accounting practices (Bharadwaj, Bharadwaj, \& Konsynski, 1999). Moreover, as the share price is a key input in the computation of Tobin's Q, changes in share prices potentially partly reflect investors' reactions to GB performance.

\subsection{Empirical models and variable definitions}

We adopt a lead-lag approach in all our regression models to address potential endogeneity issues arising from reverse causality related to $G B P I$ and $F P$. We estimate model (1) to test H1:

$$
\begin{aligned}
\text { TOBINQ }_{i, t+1}=\beta_{0}+ & \beta_{1} \text { GBPI }_{i, t}+\beta_{2} \text { SIZE }_{i, t}+\beta_{3} L E V_{i, t}+\beta_{4} \text { RISK }_{i, t}+\beta_{5} \text { PROFIT }_{i, t}+\beta_{6} \text { LIQUID }_{i, t} \\
& +\beta_{7} \text { FAGE }_{i, t}+\beta_{8} \text { GROWTH }_{i, t}+\beta_{9} \text { FOREIGN }_{i, t}+\beta_{10 I N S T_{i, t}}+\beta_{11} \text { GOVT }_{i, t} \\
& +\sum Y E A R_{i, t}+\varepsilon_{i, t}
\end{aligned}
$$

All variable definitions appear in Table 1. The variable of interest in model (1) is GBPI: a significant positive coefficient for GBPI will support our H1.

\section{[INSERT TABLE 1 ABOUT HERE]}

We extend model (1) by incorporating an interaction term between GBPI and PCON to test H2:

$$
\begin{aligned}
& T O B I N Q_{i, t+1}=\beta_{0}+\beta_{1} G B P I_{i, t}+\beta_{2} G B P I_{i, t} \times P C O N_{i, t}+\beta_{3} P C O N_{i, t}+\beta_{4} S_{I Z E_{i, t}}+\beta_{5} L E V_{i, t} \\
& +\beta_{6} R_{I S K_{i, t}}+\beta_{7} \text { PROFIT }_{i, t}+\beta_{8} L_{I Q U I D}{ }_{i, t}+\beta{ }_{9} F A G E_{i, t}+\beta_{10} G R O W T H_{i, t} \\
& +\beta_{11} F_{O R E I G N}{ }_{i, t}+\beta_{12 I N S T} \operatorname{II}_{i, t}+\beta_{13} \text { GOVT }_{i, t}+\sum Y E A R_{i, t}+\varepsilon_{i, t}
\end{aligned}
$$

In model (2), a significant and negative coefficient for $G B P I \times P C O N$ will support our $\mathrm{H} 2$.

Based on prior research, we include several control variables in our research models. We control for firm size (SIZE) as larger firms are more likely to enjoy economies of scale which may result in improved FP (Bose et al., 2017a; Al Farooque, van Zijl, Dunstan, \& Karim, 
2007; Wang \& Qian, 2011). We control for leverage (LEV) and market risk (RISK) to capture the various dimensions of firm risk that may influence FP; for example, leverage affects FP through the debt holder's monitoring activities (Roll, Schwartz, \& Subrahmanyam, 2009). Furthermore, Muttakin et al. (2015) argue that higher levels of market risk (RISK) exert a greater impact on FP. On the other hand, higher profitability may also indicate a firm's maturity, which may contribute to limited growth opportunities (Roll et al., 2009). Therefore, we control for profitability (PROFIT). We control for a firm's share trading volume (LIQUID) as a higher trading volume indicates greater demand for a share that may positively influence FP (Bose et al., 2017b; Roll et al., 2009). Moreover, we include the age (FAGE) of a banking firm as the firm will gain a competitive advantage in the market through its long-term existence (Bose et al., 2017a; Wang \& Qian, 2011).

We also control for revenue growth (GROWTH) to capture the impact of growth on FP. As Bose et al. (2017a) note, firms with higher revenue growth perform better than others. Foreign ownership (FOREIGN), institutional ownership (INST) and government ownership $(G O V T)$ variables are included to control for the influence of these different stakeholder groups generally considered to be monitoring agents (Khanna \& Palepu, 2000). Government-linked firms also have less incentive to control agency problems, can have easy access to finance, are less exposed to the market for corporate control and have weaker monitoring by shareholders (Mak \& Li, 2001): FP is likely to be poorer due to all these factors.

\subsection{Estimation methods}

Initially, our study employs the ordinary least squares (OLS) regression technique to estimate all our regression models. To check our results' robustness, we employ difference-indifferences (DiD) analysis, generalised method of moments (GMM) and Heckman's (1979) two-stage estimation approach. We also utilise robust standard errors clustered using both bank 
and year to control heteroscedasticity and serial correlation issues in the models. In all our regressions, we use year fixed effects.

\section{EMPIRICAL RESULTS}

\subsection{Descriptive statistics and correlations}

Table 2, Panel A presents the descriptive statistics of the variables used in this study. The mean (median) TOBINQ of firms in our sample is 1.092 (1.048). The mean (median) GBPI of 0.287 (0.238) suggests that banking firms have engaged in, on average, $28.70 \%$ of the $21 \mathrm{~GB}$ activities listed in our index. Consistent with Muttakin et al. (2015), 55.80\% of our firm-year observations are associated with political connections.

\section{[INSERT TABLE 2 ABOUT HERE]}

In Table 2, Panel A, among the other key variables, the mean (median) SIZE, measured by the natural logarithm of total assets of firms in our sample, is 11.445 (11.456), indicating average total assets of BDT 111,751 million (US\$1,432.71 million). The mean (median) leverage $(L E V)$ ratio is $0.930(0.918)$. The mean (median) profitability (PROFIT) is $1.20 \%$ (1.30\%). The mean $F A G E$ value of 2.313 suggests that banking firms in our sample are, on average, 10.1 years old. Institutional investor ownership (INST) is $13.00 \%$, which is close to $13.20 \%$ reported by Bose et al. (2017a).

Table 2, Panel B compares the means and medians of the overall GBPI and its three components before and after the 2011 GB directive. As is evident in Panel B, overall mean (median) GBPI improved from $0.094(0.048)$ before the GB directive to $0.489(0.524)$ after the directive. Differences between the means and medians are statistically significant at the $1 \%$ level (two-tailed tests). Similar differences are observed in the GBPI components of cost efficiency and non-financial benefits. 
Table 3 reports the Pearson's bivariate correlation matrix of the main variables. GBPI is positively correlated to Tobin's Q $(r=0.369)$, bank size $(r=0.616)$ and bank age $(r=0.180)$, while it is negatively correlated to risk $(r=-0.221)$, bank liquidity $(r=-0.484)$, growth $(r=-0.329)$ and foreign ownership ( $r=-0.187)$. Further, TOBINQ is negatively correlated to bank size ( $r=-$ $0.205)$, leverage $(r=-0.250)$, institutional ownership $(r=-0.160)$ while it is positively correlated to PROFIT ( $r=0.413)$, LIQUID $(r=0.499)$ and GROWTH $(r=0.329)$. All these coefficients are significant at least at the $1 \%$ level but no coefficient exceeds 0.8 , with Gujarati and Porter (2009) suggesting that bivariate correlations less than 0.8 do not create any multicollinearity problems. The mean variance inflation factor (VIF) of the variables is 2.92 , ranging from $1.18-$ 6.30. A VIF higher than 10 is viewed as leading to potential multicollinearity concerns (Gujarati \& Porter, 2009). Thus, our results are unlikely to suffer from multicollinearity problems.

\section{[INSERT TABLE 3 ABOUT HERE]}

\subsection{Results of multivariate regressions}

We report the regression results of models (1) and (2) in Table 4. The adjusted $R^{2}$ of model (1) is $88.10 \%$ and that of model (2) is $88.40 \%$. The positive coefficient of GBPI $(\beta=0.060, t$ statistic $=1.813$ ) is statistically significant at the $10 \%$ level in model (1), supporting our H1. In terms of economic significance, the estimated coefficient suggests that a one standard deviation increase in GBPI is associated with a $9.43 \%$ increase in the standard deviation of $T O B I N Q$ $[0.261 \times 0.060 / 0.166 \times 100]$

\section{[INSERT TABLE 4 ABOUT HERE]}

In Table 4, model (2), the positive coefficient of $G B P I(\beta=0.099, t$-statistic $=2.348)$ is statistically significant at the $5 \%$ level. In contrast, the negative coefficient of $G B P I \times P C O N$ $(\beta=-0.066, t$-statistic $=-2.161)$ is statistically significant at the $5 \%$ level. This indicates that political connections attenuate the positive GB performance-FP association. That is, banking 
firms with political connections demonstrate lower FP compared to those firms without political connections. Thus, $\mathrm{H} 2$ is also supported.

Regarding control variables, we document a negative association of banking firm size (SIZE), profitability (PROFIT) and government ownership (GOVT) with FP as shown in Table 4, models (1) and (2). We also document the positive association of FP with leverage (LEV), liquidity (LIQUID) and firm age $(F A G E) .{ }^{16}$ Although the significant relationships between these control variables and FP are generally in line with our expectations, we document a negative association between banking firm size and FP which we interpret as being due to larger banks having relatively lower valuations than smaller banks. Larger banks may have relatively higher agency costs that cannot be effectively minimised, in comparison to the case of smaller banks (Agrawal \& Knoeber, 1996; Claessens, Djankov, Fan, \& Lang, 2002). Further, the negative coefficient on profitability (PROFIT) suggests that higher profitability signals bank maturity and limited future growth options (Roll et al., 2009).

Table 5 shows the results of our re-estimation of models (1) and (2) using the three components of GBPI: cost efficiency, revenue growth and non-financial benefits. In the six estimates, the coefficients of COST_EFICIENCY $(\beta=0.051$ in model [1] and $\beta=0.065$ in model [2]) are positive as expected and significant at the $1 \%$ level. On the other hand, between the two coefficients of REVENUE_GROWTH ( $\beta=0.026$ in model [1] and $\beta=0.059$ in model [2]), only the coefficient in model (2) is significant and only at the $10 \%$ level. Similarly, the coefficient of NON_FINANCIAL $(\beta=0.087)$ is positive and significant at the $5 \%$ level in model (2) only. Overall, these results suggest that cost efficiency achieved through GB is the main driver of the GB-FP link. Furthermore, we observe that firms' political connections (PCON) significantly counterbalance the non-financial benefits of GB (coefficient of $G B P I \times P C O N$ for non-financial benefits $=-0.086, t$-statistic $=-2.195$, significant at $5 \%$ ). That is, banks probably suffer from reputational damage and lose credibility for their GB activities in the eyes of 
investors when they have political connections. Overall, the political connection of banks impairs market reputation through encouraging firm owners/managers to engage in politically motivated green activities that please political leaders at the expense of benefits for all stakeholders that is negatively evaluated by the investors.

$$
\text { [INSERT TABLE } 5 \text { ABOUT HERE] }
$$

\section{ENDOGENEITY TESTS}

\subsection{Difference-in-differences (DiD) and propensity score matching (PSM) analyses}

We employ a difference-in-differences (DiD) analysis framework to address endogeneity concerns in our findings. The DiD analysis compares changes in the FP of firms in our sample in the banking industry (treatment sample) with changes in the FP of control firms outside the banking industry (control sample) during the sample period. ${ }^{17}$ Specifically, we employ the following model:

$$
\begin{aligned}
& \text { TOBINQ }_{i, t+1}=\beta_{0}+\beta_{1 T R E A T} T_{i, t}+\beta_{2} \text { TREAT }_{i, t} \times P_{O S S} T_{i, t}+\beta_{3} P O S T_{i, t}+\beta_{4} S I Z E_{i, t}+\beta_{5} L E V_{i, t} \\
& +\beta_{6} \text { RISK }_{i, t}+\beta_{7} \text { PROFIT }_{i, t}+\beta{ }_{8} \text { IIQUID }_{i, t}+\beta 9 F A G E_{i, t}+\beta_{10} G R O W T H_{i, t} \\
& +\beta_{11} \text { FOREIGN }_{i, t}+\beta_{12} I_{N S T} T_{i, t}+\beta_{13} \text { GOVT }_{i, t}+\sum Y E A R_{i, t}+\varepsilon_{i, t}
\end{aligned}
$$

where TREAT is an indicator variable taking the value of 1 if the firm operates in the banking industry, and 0 otherwise; while POST takes a value of 1 for years after the issuance of the GB regulatory guidelines (sample years: 2011-2013), and 0 otherwise (sample years: 2008-2010). All other variables are defined in Table 1. Our variable of interest is the coefficient for TREAT $\times P O S T$ which captures the changes in FP for our treatment sample relative to the changes in FP for our control sample, subsequent to the issuance of the GB regulatory guidelines. A positive coefficient for the interaction term $(T R E A T \times P O S T)$ would support our prediction that GB regulatory guidelines significantly improved GB performance in the banking industry relative to other industries. 
For estimating model (3), we collect control sample data from non-banking industries in Bangladesh. ${ }^{18}$ However, our treatment sample is unlikely to be random. Therefore, we combine DiD analysis with the PSM approach to address the concern of non-random sample selection as well as to make our treatment and control samples comparable (Chen, Hung, \& Wang, 2018). The PSM procedure involves a logistic regression in the first stage to estimate the probability of being a treatment firm. We include size (SIZE), leverage (LEV), firm risk (RISK), profitability (PROFIT), liquidity (LIQUID), firm age (FAGE), growth (GROWTH), foreign ownership (FOREIGN), institutional ownership (INST) and government ownership (GOVT) in the first-stage regression as determinants. ${ }^{19}$ Using the predicted propensity score from the first-stage regression, we match without replacement a firm-year observation with a TREAT set equal to 1 (a treatment observation) against another non-banking firm-year observation with a TREAT set equal to 0 (a control observation). We use the caliper matching method and match within a caliper of $3 \%$, where the caliper is the difference in predicted probabilities between the treatment observation and the control observation (Dehejia \& Wahba, 2002).

Table 6, Panel A presents the first-stage logistic regression results. In our first-stage regression, we use 172 treatment and 579 control firm-year observations. Panel B reveals that the two samples are statistically similar with no significant $t$-statistics and, hence, are comparable. As Panel C reveals, in each estimate of model (3), the full sample and the PSM sample, the coefficient for TREAT $\times P O S T$ is positive and statistically significant $(\beta=0.523, t$-statistic $=5.437$ and $\beta=0.633, t$-statistic $=2.247$, respectively $)$. Overall, we conclude that our findings are robust to endogeneity concerns.

[INSERT TABLE 6 ABOUT HERE]

\subsection{Reverse causality}


The ordinary least squares (OLS) regression results reported in Table 4 may, however, be biased due to reverse causality. Strong FP in the previous period may improve a firm's currentyear GB performance. Specifically, Waddock and Graves (1997) argue that financially successful firms may have more resources, and therefore can be more motivated to invest in non-financial activities, which is consistent with the slack resources theory. To mitigate concerns surrounding reverse causality, we include an additional control variable - lagged FP $\left(T O B I N Q_{t}\right)$ - as an instrumental variable in our baseline regression model, following El Ghoul, Guedhami, Kwok and Mishra (2011). We estimate this dynamic panel data model using the system GMM technique developed by Blundell and Bond (1998). ${ }^{20}$ Table 7 reports the GMM regression results, which show that our main findings remain qualitatively similar after considering the possibility of reverse causality flowing from FP to GB performance. Moreover, the statistically insignificant Sargan test of over-identification due to instrumental variables confirms the validity of the over-identification restriction. The serial correlation tests for the first-order autocorrelation $[\mathrm{AR}(1)]$ and second-order autocorrelation $[\mathrm{AR}(2)]$ also confirm that our results contain no serial correlation. Thus, the specification tests for all our estimated regression models show that the estimations are unbiased and consistent. Overall, we find evidence that: (1) higher GB performance leads to higher FP; (2) cost efficiency and nonfinancial benefits of GB are the main drivers of this relationship ${ }^{21}$; and (3) banks' political connections negatively moderate the FP-GB relationship by offsetting the non-financial benefits of GB due to political connections.

[INSERT TABLE 7 ABOUT HERE]

\section{ADDITIONAL ANALYSIS AND ROBUSTNESS CHECKS}

\subsection{Potential mechanisms linking GB performance and financial performance}

We then test a potential underlying mechanism through which GB activities enhance financial performance (FP). Specifically, we focus on institutional investors as prior studies suggest that 
monitoring by institutional investors is related to better FP (Ferreira \& Matos, 2008) and institutional investors drive for greater CSR performance (Dyck, Lins, Roth, \& Wagner, 2019). Therefore, we examine the association between $G B P I$ and institutional investor ownership (INST). Table 8 reports the regression results. The variable $G B P I(\beta=0.093, t$-statistic $=1.656)$ is positive and statistically significant. Although the significance level is weak, the results provide some evidence that GBPI attracts institutional investors.

$$
\text { [INSERT TABLE } 8 \text { ABOUT HERE] }
$$

\subsection{Propensity score matching (PSM) analyses}

We also run PSM analysis within our sample to address endogeneity concern arising from selection bias due to observable differences between the treatment and the control firms. ${ }^{22} \mathrm{We}$ create a dummy variable based on the yearly median of $G B P I$. We assign a score of 1 if a banking firm has GBPI higher than or equal to the yearly median of GBPI (HIGH_GBPI) and 0 otherwise. In the first-stage regression, we include size (SIZE), leverage ( $L E V)$, firm risk (RISK), profitability (PROFIT), liquidity (LIQUID), firm age (FAGE), growth (GROWTH), foreign ownership (FOREIGN), institutional ownership (INST) and government ownership $(G O V T)$ as determinants. Using the predicted propensity score from the first-stage logistic regression, we match without replacement a firm-year observation with a $H I G H \_G B P I$ set equal to 1 , a treatment observation, against another firm-year observation with a $H I G H \_G B P I$ set equal to 0 , a control observation. As in our earlier analysis, we use the caliper matching method and match within a caliper of 3\%. Appendix B presents the first-stage regression (Panel A) and the comparison of control variables between the two samples (Panel B). Table 9 presents the second-stage regression results for the PSM sample. The coefficient for HIGH_GBPI is positive and statistically significant in column (1), and the coefficient for $H I G H \_G B P I \times P C O N$ is negative and statistically significant in column (2). Overall, we conclude that our findings are robust to endogeneity concerns. 


\section{[INSERT TABLE 9 ABOUT HERE]}

\subsection{Alternative measures of financial performance (FP) and GBPI}

In our baseline regression model, we used Tobin's Q to measure FP; however, the potential measurement error associated with Tobin's Q may create bias. ${ }^{23}$ Therefore, we use two transformations of Tobin's Q (TOBINQ): the inverse of TOBINQ $(-1 / T O B I N Q)$ and the natural logarithm of TOBINQ following prior studies (Bose et al., 2017b; Ferreira \& Matos, 2008). Table 9, Columns (3)-(6) present the results indicating that the coefficients for GBPI and $G B P I \times P C O N$ retain the same sign and significance level, as reported in Table $4 .{ }^{24}$ Furthermore, following Cochran and Wood (1984), we use an alternative proxy for a bank's FP, namely, operating earnings to assets ratio divided by operating earnings to sales ratio $(O P E A R N)$. This proxy measures the asset turnover that captures the effectiveness of banks' use of assets when they generate revenue. Table 9, Columns (7) and (8) report the regression results which indicate that the coefficient for $G B P I$ is positive and statistically significant (shown in column [7]). The coefficient for $G B P I \times P C O N$ is not statistically significant in column (8). The insignificant results could be due to type II error following from our small sample.

Furthermore, in our main analyses, we use the scaled score for GB performance (GBPI). In addition, we use the unscaled score as an alternative proxy for a firm's GB performance. As indicated in Table 9, Columns (9) and (10), the coefficients for our hypothesised variables retain the same signs and similar significance levels as those in our main results in Table 4.

\subsection{Heckman's (1979) two-stage analysis}

Furthermore, while banks' disclosure of GB activities could be motivated by the perceived benefits of these activities, some banks may avoid engaging in any GB activities due to a lack of perceived benefits, a decision which may create self-selection bias. We address selfselection bias using Heckman's (1979) two-stage approach. The determinants model of 
GB engagement decisions is run in the first stage using a Probit regression. An OLS regression of FP on GB performance is run in the second stage. In this regression, we include the inverse Mills ratio (IMR) generated from the first-stage regression along with other control variables.

In the first-stage regression, we use banking firms' decision to engage in GB activities (GBPI_DUM) as a dummy dependent variable set equal to 1 if a bank reports any of the items mentioned in our GBPI and 0 otherwise. ${ }^{25}$ We include the industry average GB performance score (GBPI_IND); GB regulatory directive (GREEN_LAW); banking firm size (SIZE); leverage ratio (LEV); banking firm-level profitability (PROFIT); liquidity (LIQUID); firm age (FAGE); board size (BSIZE); board independence (BIND); female directors (FDIR); foreign ownership (FOREIGN); government ownership (GOVT); and institutional investor ownership (INST) as independent variables in the first stage. The inverse Mills ratio (IMR) is computed from the first stage and is added as an additional variable in the second-stage regression model. The IMR variable in this model controls the sample selection bias. In the first-stage regression, the banking industry average of GB performance scores (GBPI_IND) is used as an exclusion restriction variable. We argue that banking industry pressure may motivate a banking firm's willingness to engage in GB activities, although this does not influence banks' FP in the subsequent year. ${ }^{26}$ Following Larcker and Rusticus (2010) and Feng, Li and McVay (2009), we use a partial $R^{2}$ to test the strength of our exclusion restriction, GBPI_IND.

For reasons of brevity, we have not reported the first-stage results. However, the unreported results show that the coefficient for GBPI_IND is 3.207, with a $p$-value of 0.041 . The model has a pseudo- $R^{2}$ of $31.80 \%$ and a partial $R^{2}$ for $G B P I I N D$ of $6.23 \%$, which is significantly greater than 0 , suggesting that GBPI_IND is a suitable exclusion restriction variable for Heckman's (1979) two-stage approach. We use models (1) and (2) as the secondstage OLS model. The test results are presented in Table 9, columns (11) and (12), showing that the coefficient for $I M R$ is statistically significant at the 5\% level. Overall, sample selection 
bias does not appear to influence the main results as the coefficients for GBPI and $G B P I \times P C O N$ retain the same signs and significance levels as those presented in Table $4 .{ }^{27}$

\section{CONCLUSIONS}

In this study, the relationship between GB performance and FP is examined using a unique Bangladeshi regulatory setting. The role of corporate political connections as a moderator of the GB performance-FP association is also investigated. We find that GB performance is positively associated with the FP of banks. We further document that the cost efficiency of GB is the main driver of this FP improvement. Unlike prior studies that document firms' ability to engage in CSR activities due to their political affiliations (Di Giuli \& Kostovetsky, 2014), we find that investors question the real motives of engaging in GB when banks have political connections, viewing the GB-FP relationship as diminished by banks' political connections.

Our findings have important policy implications for bank regulators, governments, policy advocacy groups and environmental activists. The finding that banks that 'do good' can also do well financially is a win-win situation for, on the one hand, bank managers and investors and, on the other hand, for all external stakeholders including environmental activist groups. Thus, the greening of bank business models and their operations can be a very potent tool in the fight against global warming. Given that banks play a pivotal role in financing commerce and investments, GB could be the catalyst for the transition to a low-carbon economy worldwide. Nevertheless, decision-makers of banks should be cautious and monitor whether their green activities are free from political motivation/connection. In this regard, banks executives should be careful when maintaining close ties with members of political parties because this political connection, while may be beneficial for banks in other cases, but diminish shareholders value even if banks involve in green activities.

Our study is subject to some limitations. One obvious limitation is that GB performance is measured through GB disclosure. Thus, like all other disclosure studies, a one-to-one 
relationship may not exist between the two. As argued in previous studies (Brooks \&

Oikonomou, 2018), the measurement of a firm's CSR performance originates mainly from the

firm's CSR disclosures. Moreover, the observed effects of GB performance on FP may not be

able to be replicated in countries that may already have very high levels of GB activities on a

voluntary basis. As our study is premised on a single country, future research could extend this

study to a cross-country setting to understand whether the benefits of GB performance are

conditional on institutional settings and to determine the key contextual challenges of

implementing GB initiatives.

\section{ENDNOTES}

${ }^{1}$ Green banking (GB) performance is not directly observable. Thus, we need to rely on the disclosure of GB activities by firms in the sample as the proxy for GB performance.

${ }^{2}$ We use a market-based performance measure (Tobin's Q) instead of an accounting-based measure. Tobin's Q is predominantly a market-based measure because a firm's market capitalisation reflects the firm's value as perceived by investors. Cross-sectional variations in firm performance and thus firm value are more likely to be reflected in market capitalisation rather than in any accounting-based measures. Relative to market capitalisation, book value of assets and debts are likely to be more stable over time and across firms due to their historical costbased measures. Thus, it is the magnitude of market capitalisation as captured in Tobin's Q that is going to cause more of the cross-sectional and time-wise variations in Tobin's Q. Moreover, unlike accounting-based measures (such as ROA or ROE), Tobin's Q captures more of a firm's future performance through its inclusion of the market capitalisation. We use the terms 'financial performance' interchangeably with 'firm performance'.

${ }^{3}$ For example, banks in the United Kingdom (UK) and France have faced similar types of protests by environmental activists in recent years for financing projects related to fossil fuel and forest destruction. For details, see https://www.greenpeace.org.uk/news/barclays-banks-climate-change-fossil-fuels/ and https:/uk.reuters.com/article/us-climatechange-france/climate-change-protesters-descend-on-frances-socgenenergy-companies-idUKKCN1RV0ID

${ }^{4}$ Other countries that have adopted green banking (GB) are: Brazil (2014), China (2012), Indonesia (2014), Kenya (2015), Nigeria (2012), Peru (2015), South Africa (2014), Turkey (2014), Vietnam (2015) and five others (Colombia, Ecuador, Mexico, Mongolia and Morocco) in 2016.

${ }^{5}$ We thank the Assigned Editor for pointing us in this direction.

${ }^{6}$ To illustrate, Shujan (a civil society group working to ensure good governance in Bangladesh), in its published report in 2014, revealed that half the members of the tenth Bangladesh Parliament (2014-2018) were associated with businesses and had a previous business background: more than $65 \%$ of the total 350 members were billionaires. Decision-makers of firms maintain close ties with political parties to achieve business advantages, often favouring powerful shareholders and rendering ineffective corporate governance mechanisms, rights of minority shareholders and management operations (Shujan, 2014).

${ }^{7}$ The CAMELS rating acronym stands for capital adequacy, asset quality, management, earnings, liquidity and sensitivity.

${ }^{8}$ The National Board of Revenue (NBR) is the regulator and collector of all government revenue in Bangladesh.

${ }^{9}$ Clarkson et al. (2011) analysed data from pulp and paper, chemicals, oil and gas, metals and mining industries.

${ }^{10}$ The non-financial performance (e.g., market reputations) arises from different sustainability activities which might impact on firms' performance, bringing other benefits such as reductions in the cost of capital. For a detailed discussion, see Huang and Watson (2015).

${ }^{11}$ This local newspaper's report also documented that, in order to curb such poor and abusive green activity practices, the Bangladesh Government's Ministry of Finance temporarily suspended green and CSR activities of 
state-owned banks during 2013 (The Independent, 2017). However, this investigation is beyond the scope of the current study.

${ }^{12}$ The two stock exchanges in Bangladesh are the Dhaka Stock Exchange (DSE) and the Chittagong Stock Exchange (CSE).

${ }^{13}$ We were not able to measure green performance data from any other sources.

${ }^{14}$ To ensure the reliability of the data coding for content analysis, two coders in this study worked independently at two intervals. Firstly, the annual reports of banking firms in our sample were reviewed by the first coder who completed the coding process. Secondly, the coded data were compared by the second coder. Any disagreements between the first and second coders were resolved through re-checking the annual reports and discussing issues when they arose.

${ }^{15}$ Bose et al. (2017b) reported an alpha coefficient value of 0.838 for their financial inclusion disclosure index.

${ }^{16}$ The natural logarithm of the number of years since a firm's inception is also used as a proxy for firm age. This alternative proxy did not affect our main findings.

${ }^{17}$ We thank an anonymous reviewer and the Assigned Editor for suggesting the PSM and difference-in-differences analyses.

${ }^{18}$ The focus of the current study is examining the association between GBPI and financial performance (FP). As the regulatory directive for GB was solely applicable to the banking industry, we use out-of-sample data for running the difference-in-differences (DiD) analysis. The control firms operate in various industries including construction, food, textiles/printing/publishing, chemicals, pharmaceuticals, manufacturing, computers, transportation, utilities, retail, insurance, services and others.

${ }^{19} \mathrm{We}$ did not include industry control in our first-stage PSM model because, in the DID-PSM matching, control firms are, by design, all from the non-banking industry.

${ }^{20}$ For details, see https://www.stata.com/features/overview/dynamic-panel-data/

${ }^{21}$ We also run the GMM regression for the three components of GBPI: cost efficiency, revenue growth and nonfinancial benefits. The unreported results show that the coefficient of GBPI for cost efficiency and non-financial benefits is positive and statistically significant $(\beta=0.041, t$-statistic $=7.940$ and $\beta=0.061, t$-statistic $=3.300)$, respectively. We also find the coefficient of $G B P I \times P C O N$ for non-financial benefits is negative and statistically significant $(\beta=-0.093, t$-statistic $=-2.23)$. However, the coefficient of $G B P I \times P C O N$ for cost efficiency and revenue growth is insignificant.

${ }^{22}$ In the DID-PSM analysis, we utilize the control firms from the non-banking industries. In this PSM analysis, we construct the control firms within the banking industry as the focus of our study is the banking industry.

${ }^{23}$ Tobin's Q is used as a proxy for unobservable investment opportunities. It may be associated with measurement error due to a conceptual gap between true investment opportunities and the observable measures of Tobin's Q (Erickson \& Whited, 2012).

${ }^{24}$ In our baseline regression model, we use one-year lead of Tobin's Q. We also use two-years lead of Tobin's Q as an alternative measure of FP. We do not report the results due to brevity. However, the unreported results show that the tenor of our findings remains the same.

${ }^{25}$ We used 146 banking firm-year observations for Heckman's first-stage model from which 103 banking firmyear observations were classified as $G B P I \_D U M=1$ and 43 banking firm-year observations were classified as $G B P I D U M=0$. Although the GB regulatory directive applies to all banks in Bangladesh, some banks do not comply with the requirements.

${ }^{26}$ We argue that a bank's FP might be influenced by its GB performance (GBPI). However, it is extremely unlikely that the industry average GB performance (GBPI_IND) is related to the FP of individual banks as many banks are included in the industry. Prior studies also use the industry average of the variable of interest as an exclusion restriction (Cheng, Ioannou, \& Serafeim, 2013; Jiraporn \& Chintrakarn, 2013) and, thus, this instrument meets the exclusion restriction criteria. However, we acknowledge the limitations of GBPI_IND as a perfect exclusion restriction.

${ }^{27}$ Following Lennox, Francis and Wang (2012), we test the multicollinearity of the IMR which is 5.97. Multicollinearity is considered to be high (very high) when the VIF exceeds 10 (20) (Lennox et al., 2012). As the VIF of our IMR is within this range, multicollinearity does not appear to be a problem. 


\section{REFERENCES}

ABC News (2012). Bank backlash warning over pulp mill support. 17 January. Available at https://mobile.abc.net.au/news/2012-01-17/green-groups-warn-of-bank-backlashover-pulp-mill/3778966?pfmredir $=$ sm\&pfm $=$ sm (accessed 30 September 2020).

Agrawal, A., \& Knoeber, C. R. (1996). Firm performance and mechanisms to control agency problems between managers and shareholders. Journal of Financial and Quantitative Analysis, 31, 377-397.

Ahmed, S., \& Uddin, S. (2018). Toward a political economy of corporate governance change and stability in family business groups: A morphogenetic approach. Accounting, Auditing and Accountability Journal, 31, 2192-2217.

Al Farooque, O., van Zijl, T., Dunstan, K., \& Karim, A. W. (2007). Corporate governance in Bangladesh: Link between ownership and financial performance. Corporate Governance: An International Review, 15, 1453-1468.

Al-Tuwaijri, S., Christensen, T., \& Hughes, K. (2004). The relations among environmental disclosure, environmental performance, and economic performance: A simultaneous equations approach. Accounting, Organizations and Society, 29, 447-471.

Ambec, S., \& Lanoie, P. (2008). Does it pay to be green? A systematic overview. Academy of Management Perspectives, 22, 45-62.

Asian Development Bank (ADB) (2018). Green finance in Bangladesh: Policies, institutions, and challenges. Working paper. Retrieved from https://www.adb.org/sites/default/files/publication/467886/adbi-wp892.pdf (accessed on 16 September 2020).

Bangladesh Bank (BB). (2012). Reporting green banking activities under Phase II. Bangladesh: Banking Regulation and Policy Department (BRPD Circular Letter No. 07).

from https://www.bb.org.bd/mediaroom/circulars/brpd/jul222012brpd07e.pdf (accessed 25 September 2020).

Bangladesh Bank (BB). (2014). Banking sector performance, regulation, and bank supervision: Annual report of 2014-2015. Retrieved from https://www.bb.org.bd/pub/annual/anreport/ar1415/chap5.pdf (accessed on 26 September 2020).

Bansal, P., \& Roth, K. (2000). Why companies go green: A model of ecological responsiveness. Academy of Management Journal, 43, 717-736.

Bebchuk, L. A., Cremers, K. J. M., \& Peyer, U. C. (2011). The CEO pay slice. Journal of Financial Economics, 102, 199-221.

Bharadwaj, A. S., Bharadwaj, S. G., \& Konsynski, B. R. (1999). Information technology effects on firm performance as measured by Tobin's q. Management Science, 45, 1008-1024.

Blundell, R., \& Bond, S. (1998). Initial conditions and moment restrictions in dynamic panel data models. Journal of Econometrics, 87, 115-143.

Bose, S., Khan, H. Z., Rashid, A., \& Islam, S. (2018). What drives green banking disclosure? An institutional and corporate governance perspective. Asia Pacific Journal of Management, 35, 501-527.

Bose, S., Podder, J., \& Biswas, K. K. (2017a). Philanthropic giving, market-based performance and institutional ownership: Evidence from an emerging economy. The British Accounting Review, 49, 429-444.

Bose, S., Saha, A., Khan, H. Z., \& Islam, S. (2017b). Non-financial disclosure and marketbased firm performance: The initiation of financial inclusion. Journal of Contemporary Accounting \& Economics, 13, 263-281. 
Bose, S., Bhattacharyya, A., \& Islam, S. (2016). Dynamics of firm-level financial inclusion: Empirical evidence from an emerging economy. Journal of Banking and Finance Law and Practice, 27, 47-68.

Brooks, C., \& Oikonomou, I. (2018). The effects of environmental, social and governance disclosures and performance on firm value: A review of the literature in accounting and finance. The British Accounting Review, 50, 1-15.

Brown, S., \& Hillegeist, S. A. (2007). How disclosure quality affects the level of information asymmetry. Review of Accounting Studies, 12, 443-477.

Cahan, S. F., de Villiers, C., Jeter, D. C., Naiker, V., \& van Staden, C. (2016). Are CSR disclosures value relevant? Cross-country evidence. European Accounting Review, 25, 579-611.

Chen, Y. C., Hung, M., \& Wang, Y. (2018). The effect of mandatory CSR disclosure on firm profitability and social externalities: Evidence from China. Journal of Accounting and Economics, 65, 169-190.

Cheng, B., Ioannou, I., \& Serafeim, G. (2013). Corporate social responsibility and access to finance. Strategic Management Journal, 35, 1-23.

Chowdhury, F. D. (2009). Problems of women's participation in Bangladesh politics. The Round Table: The Commonwealth Journal of International Affairs, 98, 555-567.

Claessens, S., Djankov, S., Fan, J. P., \& Lang, L. H. (2002). Disentangling the incentive and entrenchment effects of large shareholdings. Journal of Finance, 57, 2741-2771.

Clarkson, P. M., Li, Y., \& Richardson, G. D. (2004). The market valuation of environmental capital expenditures by pulp and paper companies. The Accounting Review, 79, 329353.

Clarkson, P. M., Li, Y., Richardson, G. D., \& Vasvari, F. (2011). Does it really pay to be green? Determinants and consequences of proactive environmental strategies. Journal of Accounting and Public Policy, 30, 122-144.

Cochran, P. L., \& Wood, R. A. (1984). Corporate social responsibility and financial performance. Academy of Management Journal, 27, 42-56.

Cooke, T. E. (1989). Disclosure in the corporate annual reports of Swedish companies. Accounting and Business Research, 19, 113-124.

CSR Europe, \& GRI. (2017). Member state implementation of directive 2014/95/EU. Retrieved from

https://www.globalreporting.org/resourcelibrary/NFRpublication\%20online_version.p df (accessed 24 September 2020).

Deegan, C., \& Rankin, M. (1996). Do Australian companies report environmental news objectively? An analysis of environmental disclosures by firms prosecuted successfully by the Environmental Protection Authority. Accounting, Auditing \& Accountability Journal, 9, 50-67.

Dehejia, R. H., \& Wahba, S. (2002). Propensity score matching methods for nonexperimental causal studies. Review of Economics \& Statistics, 84, 151-161.

Di Giuli, A., \& Kostovetsky, L. (2014). Are red or blue companies more likely to go green? Politics and corporate social responsibility. Journal of Financial Economics, 111, 158180.

Diouf, D., \& Boiral, O. (2017). The quality of sustainability reports and impression management: A stakeholder perspective. Accounting, Auditing \& Accountability Journal, 30, 643-667.

Dyck, A., Lins, K. V., Roth, L., \& Wagner, H. F. (2019). Do institutional investors drive corporate social responsibility? International evidence, Journal of Financial Economics, 131, 693-714. 
El Ghoul, S., Guedhami, O., Kwok, C. C. Y., \& Mishra, D. R. (2011). Does corporate social responsibility affect the cost of capital? Journal of Banking \& Finance, 35, 2388-2406.

Erickson, T., \& Whited, T. M. (2012). Treating measurement error in Tobin's Q. The Review of Financial Studies, 25, 1286-1329.

Faccio, M. (2006). Politically connected firms. American Economic Review, 96, 369-386.

Feng, M., Li, C., \& McVay, S. (2009). Internal control and management guidance. Journal of Accounting and Economics, 48, 190-209.

Fenn, K. (2012). All about Green Banking. Retrieved from http://www.preventclimatechange.co.uk/green-banking.html (accessed on 22 September 2020).

Ferreira, M. A., \& Matos, P. (2008). The colors of investors' money: The role of institutional investors around the world. Journal of Financial Economics, 88, 499-533.

Gujarati, D. N., \& Porter, D. C. (2009). Basic econometrics. New York, NY: McGraw-Hill Irwin.

Griffin, P. A., \& Sun, Y. (2013). Going green: Market reaction to CSRwire news releases. Journal of Accounting and Public Policy, 32, 93-113.

Heckman, J. J. (1979). Sample selection bias as a specification error. Econometrica, 47, 153161.

Huang, X. B., \& Watson, L. (2015) Corporate social responsibility research in accounting. Journal of Accounting Literature, 34, 1-16.

Hughes, J. S., Liu, J., \& Liu, J. (2007). Information asymmetry, diversification, and cost of capital. The Accounting Review, 82, 705-729.

International Finance Corporation (IFC). (2017). Greening the banking system - Experiences from the Sustainable Banking Network (SBN). Retrieved from https://www.ifc.org/wps/wcm/connect/413da3f3-f306-4e99-8eee

679768463130/SBN_PAPER_G20_02102017.pdf?MOD=AJPERES (accessed on 25 September 2020).

Jiraporn, P., \& Chintrakarn, P. (2013). How do powerful CEOs view corporate social responsibility (CSR)? An empirical note. Economics Letters, 119, 344-347.

Kale, J. R., Reis, E., \& Venkateswaran, A. (2009). Rank-order tournaments and incentive alignment: The effect on firm performance. The Journal of Finance, 64, 1479-1512.

Khan, H. Z., Bose, S., Mollik, A. T., \& Harun, H. (2020). 'Green washing' or 'authentic effort'? An empirical investigation of the quality of sustainability reporting by banks. Accounting, Auditing \& Accountability Journal, doi: 10.1108/AAAJ-01-2018-3330.

Khan, H. Z., Halabi, A. K., \& Samy, M. (2009). Corporate social responsibility (CSR) reporting: A study of selected banking companies in Bangladesh. Social Responsibility Journal, 5, 344-357.

Khan, H. Z. (2010). The effect of corporate governance elements on corporate social responsibility (CSR) reporting: Empirical evidence from private commercial banks of Bangladesh. International Journal of Law and Management, 52, 82-109.

Khan, H. Z., Islam, M. A., Fatima, J. K., \& Ahmed, K. (2011). Corporate sustainability reporting of major commercial banks in line with GRI: Bangladesh evidence. Social Responsibility Journal, 7, 347-362.

Khan, H. Z, Ali, M., \& Fatima, J. K. (2014). Determinants and recent development of sustainability reporting of banks in developing countries: The case of Bangladesh. Corporate Ownership and Control, 11, 507-519.

Khan, H. Z., Bose, S., \& Johns, R. (2020). Regulatory influences on CSR practices within banks in an emerging economy: Do banks merely comply? Critical Perspectives on Accounting, 71,1-20. 
Khanna, T., \& Palepu, K. (2000). Is group affiliation profitable in emerging markets? An analysis of diversified Indian business groups. The Journal of Finance, 45, 867-891.

KPMG, Global Reporting Initiative (GRI), United Nations Environment Programme (UNEP), \& Centre for Corporate Governance in Africa. (2016). Carrots \& sticks: Global trends in sustainability reporting regulation and policy. Retrieved from https://www.carrotsandsticks.net/wp-content/uploads/2016/05/Carrots-Sticks2016.pdf (accessed on 26 September 2020).

Larcker, D. F., \& Rusticus, T. O. (2010). On the use of instrumental variables in accounting research. Journal of Accounting and Economics, 49, 186-205.

Lennox, C. S., Francis, J. R., \& Wang, Z. (2012). Selection models in accounting research. The Accounting Review, 87, 589-616.

Li, F., Minnis, M., Nagar, V., \& Rajan, M. (2014). Knowledge, compensation, and firm value: An empirical analysis of firm communication. Journal of Accounting and Economics, $58,96-116$.

Luo, X., \& Bhattacharya, C. B. (2006). Corporate social responsibility, customer satisfaction, and market value. Journal of Marketing, 70, 1-18.

Manchiraju, H., \& Rajgopal, S. (2017). Does corporate social responsibility (CSR) create shareholder value? Evidence from the Indian Companies Act 2013. Journal of Accounting Research, 55, 1257-1300.

Mak, Y. T., \& Li, Y. (2001). Determinants of corporate ownership and board structure: Evidence from Singapore. Journal of Corporate Finance, 7, 235-256.

Muttakin, M. B., Monem, R. M., Khan, A., \& Subramaniam, N. (2015). Family firms, firm performance and political connections: Evidence from Bangladesh. Journal of Contemporary Accounting \& Economics, 11, 215-230.

Orsato, R. J. (2006). Competitive environmental strategies: When does it pay to be green? California Management Review, 48, 126-142.

Porter, M. E. (1991). Towards a dynamic theory of strategy. Strategic Management Journal, $12,95-117$.

Porter, M. E., \& Reinhardt, F. (2007). Grist: A strategic approach to climate. Harvard Business Review, 85, 22-26

Porter, M. E., \& van der Linde, C. (1995a). Green and competitive: Ending the stalemate. Harvard Business Review, 73, 120-134.

Porter, M. E., \& van der Linde, C. (1995b). Toward a new conception of the environment competitiveness relationship. Journal of Economic Perspectives, 9, 97-118.

Prior, D., Surroca, J., \& Tribó, J. A. (2008). Are socially responsible managers really ethical? Exploring the relationship between earnings management and corporate social responsibility. Corporate Governance: An International Review, 16, 160-177.

Roll, R., Schwartz, E., \& Subrahmanyam, A. (2009). Options trading activity and firm valuation. Journal of Financial Economics, 94, 345-360.

Scholtens, B. (2009). Corporate social responsibility in the international banking industry. Journal of Business Ethics, 86, 159-175.

Scholtens, B., \& Dam, L. (2007). Banking on the Equator. Are banks that adopted the Equator Principles different from non-adopters? World Development, 35, 1307-1328.

Shujan. (2014). Shujan - a citizens' initiative for good governance. Retrieved from https://shujan.org/ (accessed on 25 September 2020).

Sky News. (2017). Environmental activists protest Adani mine. Retrieved from http:/www.skynews.com.au/news/top-stories/2017/07/11/environmental-activistsprotest-adani-mine.html (accessed on 16 September 2020). 
Sobhan, A. (2016). Where institutional logics of corporate governance collide: Overstatement of compliance in a developing country, Bangladesh. Corporate Governance: An International Review, 24, 599-618.

Tauringana, V., \& Chithambo, L. (2015). The effect of DEFRA guidance on greenhouse gas disclosure. The British Accounting Review, 47, 425-444.

The Guardian. (2014). Welcoming a new generation of green financial policy innovation. Retrieved from http://www.theguardian.com/sustainable-business/green-financialpolicy-new-generation (accessed on 20 September 2020).

The Independent. (2017). Poor governance, non-performing loans trigger crisis in banking sector. Retrieved from http://www.theindependentbd.com/arcprint/details/127680/2017-12-12 (accessed on 25 September 2020).

Uddin, S., Siddiqui, J., \& Islam, M. A. (2016). Corporate social responsibility disclosures, traditionalism and politics: A story from a traditional setting. Journal of Business Ethics, 151, 409-428.

United Nations Development Programme (UNDP). (2014). Bangladesh Climate Fiscal Framework (pp. 1-116). Retrieved from https://info.undp.org/docs/pdc/Documents/BGD/1695\%20ClimateChange_FullLayout \%20290914.pdf (accessed on 25 September 2020).

United Nations Environment Programme (UNEP). (2015). Designing a sustainable financial system in Bangladesh. from https://wedocs.unep.org/bitstream/handle/20.500.11822/7422/-

Designing_a_Sustainable_Financial_System_in_Bangladesh_Summary_Briefing2015Designing_a_Sustainable_Financial_System_in_Bangladesh_Summary_Briefing .pdf? sequence $=3$ \&isAllowed $=\bar{y}$ (accesse $\bar{d}$ on 26 September 2020$)$.

United Nations Framework Convention on Climate Change (UNFCCC). (2016). COP 21: Report of the Conference of the Parties on its Twenty-first Session, Paris, 30 November-13 December 2015. Retrieved from http://unfccc.int/resource/docs/2015/cop21/eng/10.pdf (accessed on 25 September 2020).

Verisk Maplecroft. (2015). Climate change and environmental risk atlas 2015. Retrieved from https://maplecroft.com/portfolio/new-analysis/2014/10/29/climate-change-and-lackfood-security-multiply-risks-conflict-and-civil-unrest-32-countries-maplecroft/ (accessed on 19 September 2020).

Waddock, S. A., \& Graves, S. B. (1997). The corporate social performance-financial performance link. Strategic Management Journal, 18, 303-319.

Wang, H., \& Qian, C. (2011). Corporate philanthropy and corporate financial performance: The roles of stakeholder response and political access. Academy of Management Journal, 54, 1159-1181.

World Bank. (2013). Warming climate to hit Bangladesh hard with sea level rise, more floods and cyclones. Retrieved from http://www.worldbank.org/en/news/pressrelease/2013/06/19/ (accessed on 26 September 2020).

World Bank. (2016). Bangladesh: Building resilience to climate change. Retrieved from http://www.worldbank.org/en/results/2016/10/07/bangladesh-building-resilience-toclimate-change (accessed on 26 September 2020).

World Bank (2020). Domestic credit to private sector ( $\%$ of GDP). Available at https://data.worldbank.org/indicator/FS.AST.PRVT.GD.ZS?end=2018\&start=1960\& view $=$ chart (accessed on 23 September 2020).

Wu, M. W., \& Shen, C. H. (2013). Corporate social responsibility in the banking industry: Motives and financial performance. Journal of Banking \& Finance, 37(9), 3529-3547. 